\title{
Transplantation of Sendai Viral Angiopoietin-1- Modified Mesenchymal Stem Cells for Ischemic Heart Disease
}

\author{
Jianhua Huang ${ }^{1,4}$, Huishan Wang ${ }^{2}$ and Hirofumi Hamada ${ }^{3}$ \\ ${ }^{1}$ Department of Cardiothoracic Surgery, Ningxia People's Hospital, YinChuan, \\ 2Department of Cardiac Surgery, Shenyang Northern Hospital, Shen Yang, \\ ${ }^{3}$ Department of Molecular Medicine, Sapporo Medical University, Sapporo, \\ ${ }^{4}$ Department of Tissue Engineering, LiaoNing Medical University, Jinzhou, \\ ${ }_{1,2,4}$ China \\ ${ }^{3}$ Japan
}

\section{Introduction}

Ischemic heart disease is one of the major threatens to human heath. Despite great advances in the treatment of it, the cardiac infarction caused by heart ischemia still represents a significant cause of morbidity and mortality. Recently, MSCs therapy has been emerged as one of the potential treatments for ischemic heart disease [1-4]. Although MSCs can differentiate into endothelial [5], cardiac cell [6], and secret a range of cytokines [7], there are mounting evidences which showed paracrine effect is the major mechanism for the therapeutic effect of MSCs in the ischemic heart [8-10]. Thus, the supplement of genes that can enhance angiogenesis or cell survival is one of the attractive strategies for MSCs therapy [11].

The Ang- 1 has been reported to improve angiogenesis in ischemic heart $[12,13]$. Ang-1 has also been found as an apoptotic survival factor [14-16]. Therefore, the combination of Ang-1 gene and MSCs would be an alternative method to enhance the effects of MSCs. However, when performing the combination of Ang-1 gene and MSCs therapy, a vector that has high transductive efficiency to MSCs is needed.

Sendai virus is a murine parainfluenza virus type I, and is a single-stranded RNA virus. Sendai virus is considered to be non-pathogenic to humans [17]. Efficient gene transduction into various primary cultured cells and tissues by recombinant virus vector has been reported [18-22]. Furthermore, it replicates in the cytoplasma and poses no risk of integration into the genomic DNA. These characteristics of the Sendai virus make it a potential vector for combined gene and cell therapy.

In our previously study, we found Sendai viral vector $(\mathrm{SeV})$ has high transductive efficiency to MSCs even at low MOI [23]. To further investigate its clinical practicality, we infected SeV to the MSCs in vitro at low MOI with short time exposure. We also injected MSCs modified with SeVhAng-1 into the ischemic heart of rats to investigate its effect on angiogenesis and engraftment of MSCs in the ischemic heart. 


\section{Materials and methods}

\subsection{Animals}

Lewis rats were obtained from the Animal Research Centre of the Fourth Military Medical University, Xi'an (China) and maintained on a 12-hour light: 12 -hour dark in a $20-25^{\circ} \mathrm{C}$ environment. The Ethics Committee for Animal Experiments of the Fourth Military Medical University approved all animal work (Permit number: 20531) and the experimental protocols strictly complied with the institutional guidelines and the criteria outlined in the "Guide for Care and Use of Laboratory Animals".

\subsection{Sendai virus vectors}

Sendai virus vectors containing the E.coli $\beta$-galactosidase gene (SeVLacZ) or the human angiopoietin-1 gene (SeVhAng-1) were used [24]. For the construction of genomic cDNA of SeVhAng1, the human Ang-1 open reading frame was cloned from a human cDNA library and amplified using the polymerase chain reaction with primers containing SeV-specific transcriptional regulation signal sequences: 5'-TTGCGGCCGCCAAAGTTCAATGACAGTTTTCCTTTCCTTTCCTCTCTG-3'a nd5' ATTGCGGCCGCGATGAACTTTCACCCTAAGTTTTTCTTACTACGGTCAAAAATCT AAAGTTCGAATCATCATAGTTGTGGAACG-3', and was subsequently inserted into the NotI site of pSeV18+b(+) [25] to generate pSeVhAng-1. The pSeVhAng-1 was transfected into LLC-MK2 cells previously infected with vaccinia virus vTF7-3 [26], which expresses T7 polymerase. The T7-drived full-length recombinant SeVhAng-1 RNA genomes were encapsulated with $\mathrm{N}, \mathrm{P}$ and $\mathrm{L}$ proteins, which were derived from the respective cotransfected plasmids. Forty hours later, the transfected cells were injected into 10 day-old embryonated chicken eggs to amplify the recovered virus [27]. The Sendai virus titer was determined by a hemagglutination assay using chicken red blood cells, and the virus was stored at $-70{ }^{\circ} \mathrm{C}$ until use.

\subsection{MSCs source}

MSCs cultures were prepared according to the protocol reported previously. Briefly, under sterile conditions, the femur and tibia of 2 month-old male Lewis rats were excised, with special attention given to remove all connective tissue attached to bones. Bone marrow plugs were extracted from the bones by flushing the bone marrow cavity with Dulbecco's modified Eagle's medium (DMEM). Marrow plug suspension was dispersed by passing it through subsequent pipettes of decreasing sizes. After a homogenous cell suspension was achieved, the cells were plated, cultured in DMEM containing $10 \%$ fetal bovine serum, and incubated at $37^{\circ} \mathrm{C}$ humidified atmosphere with $5 \% \mathrm{CO}_{2}$ for 3 days before the first medium change.

\subsection{In vitro SeV transduction}

After 70\% conflulence of cultured MSCs in the dish, SeVLacZ at 10 MOI were infected to the MSCs with different time exposure (1 minute to 60 minutes). After $48 \mathrm{hr}$, both chmiluminescent assay of MSCs infected with SeVLacZ at 10 MOI with different time exposure and X-gal staining of MSCs infected with SeVLacZ at 10 MOI with 1 minute exposure were performed as previous described [28]. 


\subsection{Expression of hAng-1 in MSCs by SeVhAng-1 transduction}

Human Ang-1 expression in MSCs was detected after 2 days of transduction with SeVhAng1 by Western blot. MSCs were washed twice with cold PBS and suspended in a cold lysis buffer (20 mmol/L HEPES, pH 7.5, $150 \mathrm{mmol} / \mathrm{L} \mathrm{NaCl}, 1 \mathrm{mmol} / \mathrm{L}$ EDTA, 0.5\% Triton X-100, protease inhibitors [complete, Roche]). Similar quantities of the soluble fractions $(20 \mu \mathrm{g})$ were separated by SDS-PAGE, transferred onto nitrocellulose membranes, and blocked overnight in blocking solution at $4^{\circ} \mathrm{C}$. The membranes were incubated for $1 \mathrm{hr}$ with mouse anti-human monoclonal antibodies to Ang-1 (Santa Cruz Biotechnology), followed by anti-mouse secondary antibody conjugated to horseradish peroxidase (Zymed, Inc., South San Francisco, CA) for $1 \mathrm{hr}$ at room temperature. An enhanced chemiluminescence substrate system ECL Plus (Amersham Biosciences UK, Little Chalfont, UK) was used to visualize HRP. The $B$-actin protein levels were assayed as the internal control.

\subsection{Animal model}

Lewis rats (female, weight 200-250 g) were used in the experiment. The rat was anesthetized with IP injection of ketamine $(100 \mathrm{mg} / \mathrm{kg})$ and xylizine $(10 \mathrm{mg} / \mathrm{kg})$, and intubated with a 17gague needle sheath. After intubation, the rat was supported with a rodent respirator. A left lateral thoractomy was made, the heart was exposed and LAD was ligated with 6-0 suture [12]. Immediately after LAD ligation, $5 \times 10^{6}$ MSCs were injected into the heart at 2 sites of peri-infarct area of the heart.

\subsection{Evaluation of heart function}

After 4 weeks of LAD ligation, the heart function was evaluated by echocardiography as previously described [29]. FS was used as a main index for the evaluation of heart function.

\subsection{Evaluation of infarct size}

We evaluated the infarct size of the heart as previously described [12]. Four weeks after myocardial infarction, rats were deeply anesthetized with inhalation of diethyl ether, injected with a mixture of ketamine hydrochloride $(50 \mathrm{mg} / \mathrm{kg})$ and xylazine $(4 \mathrm{mg} / \mathrm{kg})$, and killed by rapid exision of the heart. The excised hearts were immediately soaked in cold saline for 10 s to remove excess blood from the ventricles and fixed in neutral-buffered $4 \%$ formalin for $48 \mathrm{~h}$. Paraffin-embedded samples were sectioned at $10 \mu \mathrm{m}$, and Masson's trichrome staining was performed to delineate scar tissue from viable myocardium. Masson's trichrome-stained sections were captured as digital images and analyzed by NIH Image software.

\subsection{Capillary density measurement}

After 28 days of LAD ligation, the heart was harvest and snap-frozen in liquid nitrogen. Cryosections of $10 \mu \mathrm{m}$ were made. The endothelial cells were stained with anti-CD31 monoclonal antibody (Pharmingen) as first antibody, followed by a biotinylated anti-mouse IgG as second antibody, and an avidin-HRP conjugate for color reaction (DAB paraffin IHC staining module, Ventana Medical Systems, Inc., Tucson, AZ). The sections were observed under microscope, 5 fields were randomly selected in the peri-infarct area of each section, and CD31-positive cells were counted in a blinded manner. The number of CD 31-positive cells in each field was used as an index of capillary density. 


\subsection{Analysis of Ang-1 expression and its effect on p-Akt in the ischemic heart}

We injected MSCs modified with or without SeVhAng-1 into the ischemic heart of the rats and determined the effect of Ang-1 overexpression on p-Akt as previously described. In brief, after 2 days injection of MSCs modified with or without SeVhAng-1 into the ischemic heart, the heart was harvested and put into $4 \mathrm{ml}$ lysis buffer, and incubated for 5 min on ice. The cardiac muscle was homogenized with a mixing homogenizer (Kinematica AG, Littau switzerland). The homogenates were heated at $95{ }^{\circ} \mathrm{C}$ for $10 \mathrm{~min}$ and centrifuged at $12,000 \mathrm{~g}$ for $10 \mathrm{~min}$. After determination of protein concentration in supernatants by BCA methods, total protein $(40 \mu \mathrm{g})$ was subjected to SDS page in $5-20 \%$ Tris-glycine gels, subsequently transferred to nitrocellulose membranes and blocked overnight in blocking solution at $4{ }^{\circ} \mathrm{C}$. The membranes were incubated for $1 \mathrm{hr}$ with mouse anti-human monoclonal antibodies to Ang-1 (Santa Cruz Biotechnology), p-Akt (ser473) and t-Akt (Signaling Technology, Beverly, MA) followed by anti-mouse secondary antibody conjugated to horseradish peroxidase (Zymed, Inc., South San Francisco, CA) or anti-rabbit secondary antibody conjugated to horseradish peroxidase (Amersham Biosciences UK, Buckinghamshire, England) for $1 \mathrm{hr}$ at room temperature. An enhanced chemiluminescence substrate system ECL Plus (Amersham Biosciences UK, Little Chalfont, UK) was used to visualize HRP.

\subsection{TUNEL staining}

After 2 days injection of MSCs modified with or without SeVhAng-1, the heart was harvested, and cryosections were cut and randomly selected for TUNEL staining as described by manufacture (Roche).

\subsection{Real-time polymerase chain reaction for MSCs survival in the ischemic heart}

Real-time PCR was performed to detect Y-chromosomal DNA in the ischemic heart of female rat injected with male MSCs as previously reported [30]. In brief, after 2 days of MSCs injection, the heart was harvested, the DNA of the tissue was extracted with the Qiagen Kit (Qiagen, Mississauga, Ontario, Canada). Real-time PCR was performed with SYBR-Green (Applied Biosystems, Foster City, Calif). The SYBR-Green I dye binds to the double-stranded product, resulting in an increase in fluorescence detected by the $A B I$ 7900HT Sequence Detection System (Applied Biosystems). A specific sequence of rat Sry3 gene in the $\mathrm{Y}$ chromosome was targeted. The genomic DNA taken from male MSCs was used to obtain a standard curve. The primer pairs were 5'-GCA TTT ATG GTG TGG TCC CGC GG-3' and 5'-GGC ACT TTA ACC CTT CGA TGA GGC-3'. The cycling conditions were 5 minutes at $50^{\circ} \mathrm{C}, 10$ minutes at $95^{\circ} \mathrm{C}$ for activation of polymerase, and then 30 seconds at $95^{\circ} \mathrm{C}$ for denaturation, 60 seconds at $62^{\circ} \mathrm{C}$ inducing annealing, and 30 seconds at $72^{\circ} \mathrm{C}$ for extension. Forty-five cycles were used. After amplification, dissociation curves were obtained to discriminate between specific and nonspecific products.

\subsection{Statistical analysis}

Data were expressed as means \pm standard deviations (SD). Statistical comparisons were performed using ANOVA followed by Bonferroni/Dunn testing. A $p$ value less than 0.05 was considered to be statistically significant. 


\section{Results}

\subsection{Transductive efficiency of SeV to the MSCs}

To determine the transductive efficiency of SeV to MSCs, we infected SeVLacZ to MSCs at $10 \mathrm{MOI}$ with 1 minute exposure, and performed X-Gal staining after $48 \mathrm{~h}$ of infection. The results showed that Sendai viral vector almost had 100\% transductive efficiency to MSCs even at $10 \mathrm{MOI}$ with 1 mintue exposure. We also performed time course effect of the Sendai viral vector on the transductive efficiency to the MSC by chemiluminescent assay. Interestingly, we found that Sendai viral vector almost had the same protein expression at every time point checked ( 1 minute to 60 minutes). This indicates Sendai viral vector is ideal candidate for combined gene and cell therapy in clinical practice for its high transductive efficiency at low MOI with short time exposure.

\subsection{SeVhAng-1 transduction to MSCs mediated efficient Ang-1 expression}

To determine the expression of hAng-1 by SeVhAng-1-modified MSCs, Western blot were performed. We used a human Ang-1 antibody which has cross reaction with rat Ang-1 for Western blot. The result showed an obviously increased expression of Ang-1 in MSCs modified with SeVhAng-1.

\subsection{SeVhAng-1-modified MSCs injection decreased heart infarction and improved cardiac function after LAD ligation}

After 4 weeks of LAD ligation, the cardiac function was evaluated by echo. The FS was 39.0 $\pm 3.5,32.0 \pm 2.8$ and $21.1 \pm 3.3$ in the SeVhAng-1-modified MSCs-, MSCs- and mediumtreated groups, respectively, and there was a significant difference between the SeVhAng-1modified MSCs and the medium $(\mathrm{p}<0.01)$, there was also a significant difference between SeVhAng-1-modified MSCs and sole MSCs $(\mathrm{p}<0.05)$. We then sacrificed rats after 4 weeks, the hearts were harvested, and Masson's trichrome staining was performed. The infarct size was $24.5 \pm 4.8 \%, 32.5 \pm 4.4 \%$ and $42.5 \pm 5.1 \%$ in the SeVhAng-1-modified MSCs-, MSCs- and medium-treated groups, respectively, and there was a significant difference between the SeVhAng-1-modified MSCs and the medium $(\mathrm{p}<0.01)$, there was also a significant difference between SeVhAng-1-modified MSCs and sole MSCs $(p<0.05)$.

\subsection{SeVhAng-1-modified MSCs injection increased capillary density in ischemic heart} After 28 days of SeVhAng-1-modified MSCs injection, the immunostaining of CD31 on the cryosections of the cardiac muscle was carried out. The capillary density was $204.8 \pm 18.3$, $150.2 \pm 16.2$ and $77.4 \pm 13.8$ per field in the SeVhAng-1-modified MSCs-, MSCs- and medium-treated groups, respectively, and there was a significant difference between the SeVhAng-1-modified MSCs and the medium $(\mathrm{p}<0.01)$, there was also a significant difference between SeVhAng-1-modified MSCs and sole MSCs $(\mathrm{p}<0.05)$.

\subsection{Overexpression of Ang-1 increased p-Akt and decreased apoptosis in the ischemic heart}

MSCs secrete numerous cytokines and growth factors in hypoxic condition. However, the Ang-1 secretion is not obvious elevated [10,31]. Thus, we inferred that Ang-1, which is secreted by SeVhAng-1-modified MSCs, would play some role during early period of cardiac infarction. To prove this, we injected MSCs modified with or without SeVhAng-1 
into the ischemic heart of rats. First, we determined by Western blot whether the overexpression of Ang-1 by MSCs had an effect on the expression of p-Akt in the ischemic heart. The result showed that p-Akt expression obviously increased in ischemic heart treated by SeVhAng-1-modified MSCs, compared with that by sole MSCs. Because activated Akt has the effect of anti-apoptosis, we further determined whether increased p-Akt decreases apoptosis in the ischemic heart. We found that overexpression of Ang-1 by SeVhAng-1-modified MSCs decreased the apoptosis which may include endothelial cells, cardiac myocytes or MSCs in the ischemic heart, compared with that by sole MSCs. We further determined whether increased p-Akt improves survival of MSCs injected into the ischemic heart. By real time detection of sry gene in the female heart tissue samples at 2 days after sex-mismatched cell transplantation, We found that overexpression of Ang-1 by SeVhAng-1-modified MSCs significantly improved survival of MSCs per se in the ischemic heart $(\mathrm{p}<0.01)$, compared with that by sole MSCs.
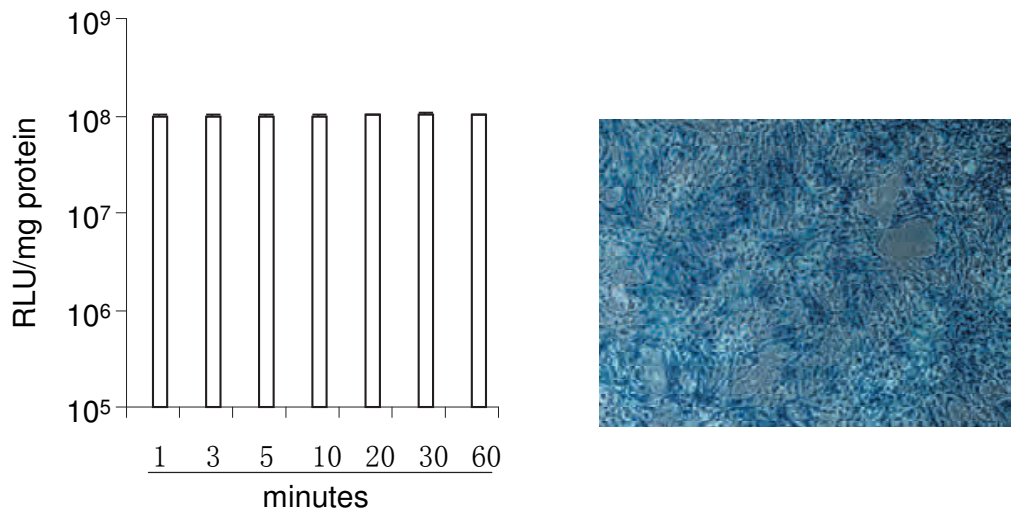

Fig. 1. Transductive efficiency of Sendai viral vector to MSCs. A, MSCs were infected with 10 MOI SeVLacZ with different time exposure, the chemiluminescent assay showed Sendai viral vector had high transductive efficiency to MSCs even with short time exposure, and 1 minute exposure by SeVLacZ almost had the same transductive efficiency to the MSCs as 60 minutes exposure did. B, X-gal staining of MSCs infected with 10 MOI Sendai viral vector.

12

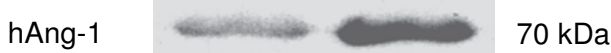

actin

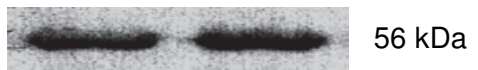

Fig. 2. SeVhAng-1 mediated efficient hAng-1 expression in MSCs. Representative Western blot detection of hAng-1 expression after 10 MOI SeVhAng-1 infected to the MSCs with 1 minute exposure. Lane 1, MSCs without transduction of SeVhAng-1; lane 2, MSCs with transduction of SeVhAng-1. The experiments were repeated 3 times. 
A

Medium

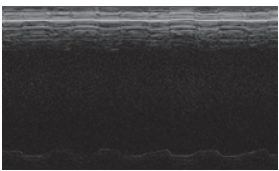

MSC

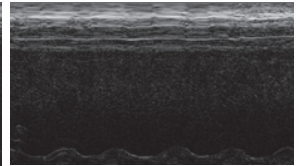

$* *$

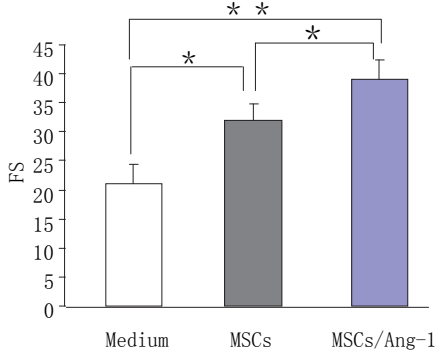

MSC/Ang-1

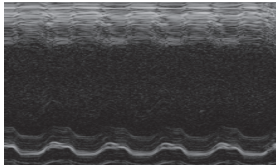

B
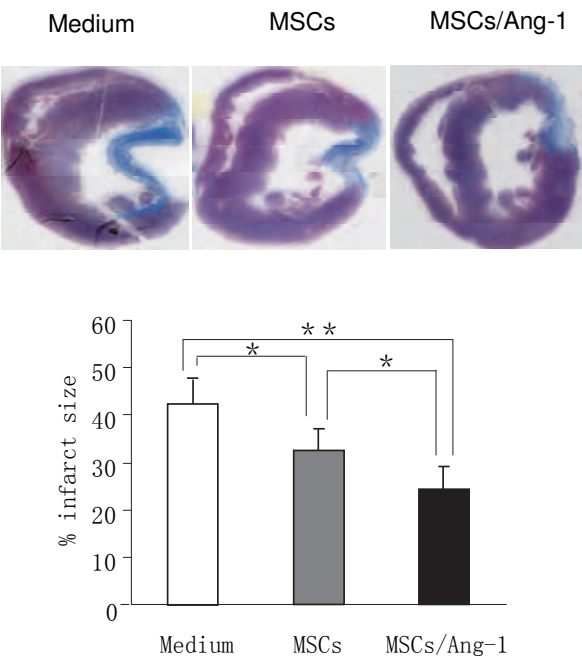

Fig. 3. Effect of SeVhAng-1 modified MSCs on heart with LAD liagation. A, representive echo measurement of cardiac function at 28 days after LAD ligation. left, ischemic heart injected with medium; middle, ischemic heart injected with MSCs; right, ischemic heart injected with SeVhAng-1 modified MSCs. SeVhAng-1 modified MSCs significantly improved cardiac function, ${ }^{*} p<0.05$ versus sole MSCs and ${ }^{* *} p<0.01$ versus medium, $\mathrm{n}=5$ in each group. B, Masson's trichrome staining of the heart at 28 days after LAD ligation. left, ischemic heart injected with medium; middle, ischemic heart injected with MSCs; right, ischemic heart injected with SeVhAng-1 modified MSCs. SeVhAng-1 modified MSCs significantly decreased infarct size, ${ }^{*} p<0.05$ versus sole MSCs and ${ }^{* *} p<0.01$ versus medium, $\mathrm{n}=5$ in each group. 

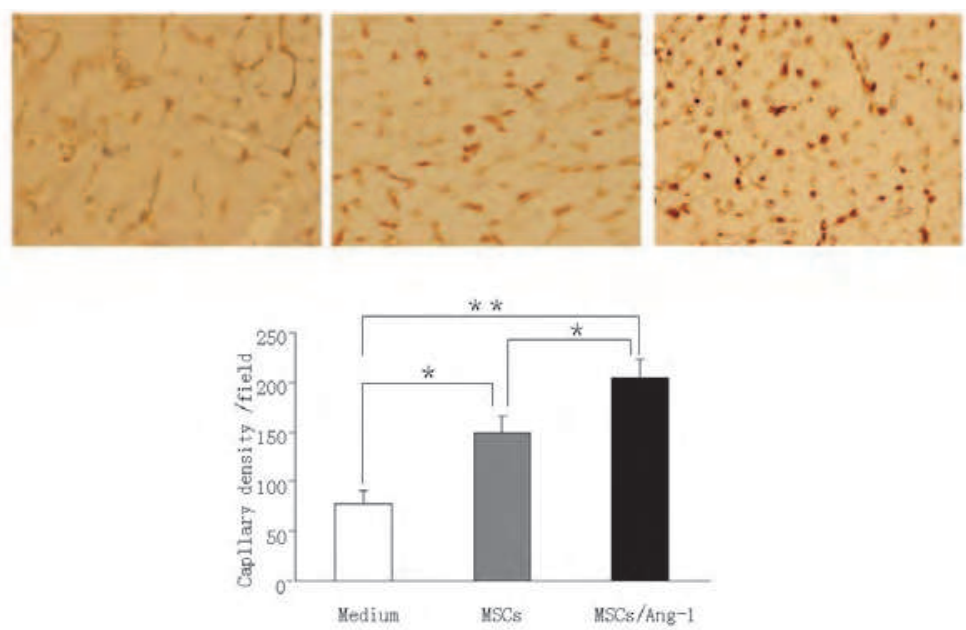

Fig. 4. A, capillary density at 28 days after injection of SeVhAng-1 modified MSCs into the ischemic heart. Left, heart injected with medium; middle, heart injected with sole MSCs; right, heart injected with SeVhAng-1-modified MSCs, magnification, $\times 400$. B, SeVhAng-1 significantly increased the capillary density compared with controls. ${ }^{*} p<0.01$ versus medium and ${ }^{*} p<0.05$ versus MSCs, $\mathrm{n}=5$ in each group.

\section{Discussion}

In the present study, we found that Sendai viral vector had high transductive efficiency to MSCs even at low MOI with short time exposure. Both MSCs modified with SeVhAng-1 and MSCs improved the cardiac function in rats after heart infarction. However, MSCs modified with SeVhAng-1 had better improvement of cardiac function, compared with sole MSCs. This indicated that SeVhAng-1-modified MSCs could serve as a more effective therapy for ischemic heart disease.

Among various vectors, adenoviral vector is widely used for combination of gene and cell therapy in recent years. However, because of lower expression of the CAR receptor for the binding of adenovirus in MSCs, the transductive efficiency of adenoviral vector to the MSCs is not so satisfactory, especially at low MOI $[23,31]$. SeV has been proved to have high transductive efficiency in a broad range of tissues, including the airway epithelial cells, vasculature tissues, skeletal muscles, activated $\mathrm{T}$ cells, stem cells and neural tissues. In our previously study, we found Sendai viral vector $(\mathrm{SeV})$ has high transductive efficiency to MSCs even at low MOI [23]. In present study, we further found that SeV had high transductive efficiency to MSCs at low MOI with short time exposure. This characteristic of $\mathrm{SeV}$ overcomes the shortcoming of needing relatively long time exposure to the MSCs by current available vectors such as adenoviral vector, and makes it an ideal vector for combined stem cell and gene therapy in clinical practice.

Although MSCs can differentiate into cardiomyocytes and endothelial cells, the magnitude of incorporation of MSCs into vascular structures or regenerating cardiomycytes is too low to explain the functional recovery of ischemic heart by MSCs. Kinnaird et al found that MSCs can secret a range of cytokines such as VEGF and bFGF in hypoxic condition and 
suggested the paracrine mechanism of MSCs is one of the major causes of angiogenetic effect by MSCs $[9,10]$. Nevertheless, hypoxic condition does not increase Ang-1 expression in MSCs $[10,32]$. Because Ang-1 plays an important role in angiogenesis, the supplement of Ang-1 seems to have significant importance for MSCs in treating ischemic heart disease. In the present study, we got a high expression of Ang-1 by transduction of SeVhAng-1 to the MSCs, which had an enhanced angiogenesis effect in the ischemic heart compared with sole MSCs.

A

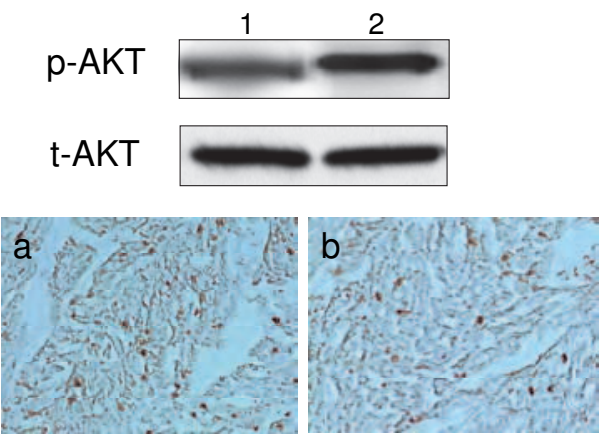

C

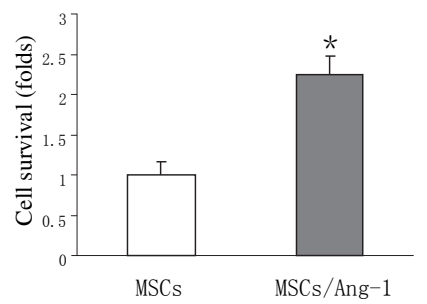

Fig. 5. Effect of overexpression of Ang-1 on p-Akt and MSCs survival in the ischemic heart. A, lane 1, heart injected with MSCs; lane 2, heart injected with SeVhAng-1- modified MSCs. SeVhAng-1- modified MSCs obviously increased expression of Ang-1 and p-Akt in the ischemic heart. The experiments were repeated 3 times. B, $a$, heart injected with MSCs; $b$, heart injected with MSCs modified with SeVhAng-1. Apoptotic cell were stained brown, magnification, $\times 400$. SeVhAng-1-modified MSCs obviously decreased apoptosis, compared with the sole MSCs. C , Real-time polymerase chain reaction for sry gene in the female heart muscle samples at 2 days after sex-mismatched cell transplantation. The fold change in sry gene expression in different animal groups was calculated. The results showed SeVhAng-1modified MSCs significantly improved MSCs survival, compared with the sole MSCs. ${ }^{*} p<$ 0.01 versus sloe MSCs.

The high rate of death occurs after MSCs transplantation because of inflammation, loss of survival signal from matrix attachments [33] and cytotoxic factors in the ischemic heart [34]. For these reasons, the enhancement of MSCs engraftment in hostile circumstance is becoming one of attractive strategies to improve its therapeutic effects [35-38]. Ang-1 prevents endothelial cell apoptosis [16] and promotes cardiac muscle survival [39] via activation of Akt pathways. Accordingly, overexpression of Ang-1 by SeVhAng-1-modified MSCs may also have protective effect to MSCs per se which is beneficial to the engraftment of MSCs in the ischemic heart. Indeed, we found SeVhAng-1-modified MSCs significantly 
increased p-AKT expression, which improved survival of MSCs injected into the ischemic heart. This protective effect by SeVhAng-1-modified MSCs would be beneficial to the enhancement of angiogenesis during the period of heart ischemia.

Our study indicated that Sendai viral vector has high transductive efficiency to the MSCs even at low MOI with short time exposure, and MSCs modified with SeVhAng-1 enhances the angiogenetic effect of MSCs. In addition, the SeVhAng-1 modification increases survival of MSCs in the ischemic heart. SeVhAng-1-modified MSCs may serve as a more effective and practical tool in dealing with ischemic heart disease.

\section{Acknowledgements}

We thank Takeo Yamamoto for his technical assistance in vector construction.

\section{Footnotes}

Competing Interests: The authors have declared that no competing interests exist.

Funding: This work was partly supported by a grant to HJ from National Natural Science foundation of China (30960379). The funders had no role in study design, data collection and analysis, decision to publish, or preparation of the manuscript. No current external funding sources for this study.

\section{References}

[1] Nagaya N, Fujii T, Iwase T, Ohgushi H, Itoh T, et al. Intravenous administration of mesenchymal stem cells improves cardiac function in rats with acute myocardial infarction through angiogenesis and myogenesis.Am J Physiol Heart Circ Physiol. 2004; 287(6):H2670-2676.

[2] Pittenger MF, Martin BJ. Mesenchymal stem cells and their potential as cardiac therapeutics.Circ Res. 2004; 95(1):9-20.

[3] Dick AJ, Guttman MA, Raman VK, Peters DC, Pessanha BS, et al. Magnetic resonance fluoroscopy allows targeted delivery of mesenchymal stem cells to infarct borders in Swine. Circulation. 2003; 108(23):2899-2904.

[4] Dai W, Hale SL, Martin BJ, Kuang JQ, Dow JS, et al. Allogeneic mesenchymal stem cell transplantation in postinfarcted rat myocardium: short- and long-term effects. Circulation. 2005; 112(2):214-223.

[5] Silva GV, Litovsky S, Assad JA, Sousa AL, Martin BJ, et al. Mesenchymal stem cells differentiate into an endothelial phenotype, enhance vascular density, and improve heart function in a canine chronic ischemia model. Circulation. 2005; 111:150-156.

[6] Toma C, Pittenger MF, Cahill KS, Byrne BJ, Kessler PD. Human mesenchymal stem cells differentiate to a cardiomyocyte phenotype in the adult murine heart. Circulation. 2002; 105:93-98.

[7] Iwase T, Nagaya N, Fujii T, Itoh T, Murakami S, et al. Comparison of angiogenic potency between mesenchymal stem cells and mononuclear cells in a rat model of hindlimb ischemia. Cardiovasc Res. 2005; 66:543-551.

[8] Gnecchi M, Zhang Z, Ni A, Dzau VJ. Paracrine mechanisms in adult stem cell signaling and therapy. Circ Res. 2008; 103(11):1204-1219. 
[9] Kinnaird T, Stabile E, Burnett MS, Shou M, Lee CW, et al. Local delivery of marrowderived stromal cells augments collateral perfusion through paracrine mechanisms. Circulation. 2004; 109:1543-1549.

[10] Kinnaird T, Stabile E, Burnett MS, Saji M, Lee CW, et al. Marrow-derived stromal cells express genes encoding a broad spectrum of arteriogenic cytokines and promote in vitro and in vivo arteriogenesis through paracrine mechanisms. Circ Res. 2004; 94:678-685.

[11] Penn MS, Mangi AA. Genetic enhancement of stem cell engraftment, survival, and efficacy. Circ Res. 2008; 102(12):1471-1482.

[12] Takahashi K, Ito Y, Morikawa M, Kobune M, Huang J, et al. Adenoviral-delivered angiopoietin-1 reduces the infarction and attenuates the progression of cardiac dysfunction in the rat model of acute myocardial infarction. Mol Ther. 2003; 8(4):584-592.

[13] Zhou L, Ma W, Yang Z, Zhang F, Lu L, et al. VEGF165 and angiopoietin-1 decreased myocardium infarct size through phosphatidylinositol-3 kinase and Bcl-2 pathways. Gene Ther. 2005; 12:196-202.

[14] Papapetropoulos A, Garcia-Cardena G, Dengler TJ, Maisonpierre PC, Yancopoulos GD, et al. Direct actions of angiopoietin-1 on human endothelium: evidence for network stabilization, cell survival, and interaction with other angiogenic growth factors. Lab Invest. 1999; 79:213-223.

[15] Holash J, Maisonpierre PC, Compton D, Boland P, Alexander CR, et al. Vessel cooption, regression, and growth in tumors mediated by angiopoietins and VEGF. Science.1999; 284:1994-1998.

[16] Kim I, Kim HG, So JN, Kim JH, Kwak HJ, et al. Angiopoietin-1 regulates endothelial cell survival through the phosphatidylinositol 3'-Kinase/Akt signal transduction pathway.Circ Res. 2000; 86(1):24-29.

[17] Bitzer M, Armeanu S, Lauer UM, Neubert WJ. Sendai virus vectors as an emerging negative-strand RNA viral vector system. J Gene Med. 2003; 5:543-553.

[18] Yonemitsu Y, Kitson C, Ferrari S, Farley R, Griesenbach U, et al. Efficient gene transfer to airway epithelium using recombinant Sendai virus. Nat Biotechnol. 2000; 18:970-973.

[19] Masaki I, Yonemitsu Y, Komori K, Ueno H, Nakashima Y, et al. Recombinant Sendai virus-mediated gene transfer to vasculature: a new class of efficient gene transfer vector to the vascular system. Faseb J. 2001; 15:1294-1296.

[20] Li HO, Zhu YF, Asakawa M, Kuma H, Hirata T, et al. A cytoplasmic RNA vector derived from nontransmissible Sendai virus with efficient gene transfer and expression. J Virol. 2000; 74:6564-6569.

[21] Okano S, Yonemitsu Y, Nagata S, Sata S, Onimaru M, et al. Recombinant Sendai virus vectors for activated T lymphocytes. Gene Ther. 2003; 10:1381-1391.

[22] Jin CH, Kusuhara K, Yonemitsu Y, Nomura A, Okano S, et al. Recombinant Sendai virus provides a highly efficient gene transfer into human cord blood-derived hematopoietic stem cells. Gene Ther. 2003; 10:272-277.

[23] Piao W, Wang $H$, Inoue $M$, Hasegawa $M$, Hamada $H$, et al. Transplantation of mesenchymal cells modified with SeVhAng1 for ischemic limb disease. Angiogenesis 2010 ; 13:203-210

[24] Huang J, Inoue M, Hasegawa M, Tomihara K, Tanaka T, et al. Sendai viral vector mediated angiopoietin-1 gene transfer for experimental ischemic limb disease. Angiogenesis. 2009; 12:243-249. 
[25] Hasan MK, Kato A, Muranaka M, Yamaguchi R, Sakai Y, et al. Versatility of the accessory $C$ proteins of Sendai virus: contribution to virus assembly as an additional role. J Virol. 2000; 74:5619-5628.

[26] Fuerst TR, Niles EG, Studier FW,Moss B. Eukaryotic transient-expression system based on recombinant vaccinia virus that synthesizes bacteriophage T7 RNA polymerase. Proc Natl Acad Sci U S A. 1986; 83:8122-8126.

[27] Kato A, Sakai Y, Shioda T, Kondo T, Nakanishi M, et al. Initiation of Sendai virus multiplication from transfected cDNA or RNA with negative or positive sense. Genes Cells. 1996; 1:569-579.

[28] Huang J, Ito Y, Kobune M, Sasaki K, Nakamura K, et al. Myocardial injection of CA promoter-based plasmid mediates efficient transgene expression in rat heart. $\mathrm{J}$ Gene Med. 2003; 5:900-908.

[29] Jiang S, Haider HKh, Idris NM, Salim A, Ashraf M. Supportive interaction between cell survival signaling and angiocompetent factors enhances donor cell survival and promotes angiomyogenesis for cardiac repair. Circ Res. 2006; 99(7):776-784.

[30] Shujia J, Haider HK, Idris NM, Lu G, Ashraf M. Stable therapeutic effects of mesenchymal stem cell-based multiple gene delivery for cardiac repair.Cardiovasc Res. 2008;77(3):525-533.

[31] Tsuda H, Wada T, Ito $Y$, Uchida H, Dehari H, et al. Efficient BMP2 gene transfer and bone formation of mesenchymal stem cells by a fiber-mutant adenoviral vector. Mol Ther. 2003; 7:354-365.

[32] Ohnishi S, Yasuda T, Kitamura S, Nagaya N. Effect of hypoxia on gene expression of bone marrow-derived mesenchymal stem cells and mononuclear cells. Stem Cells. 2007; 25:1166-1177.

[33] Zhang M, Methot D, Poppa V, Fujio Y, Walsh K, et al. Cardiomyocyte grafting for cardiac repair: Graft cell death and anti-death strategies. J Mol Cell Cardiol. 2001; 33: 907-921

[34] Geng YJ. Molecular mechanisms for cardiovascular stem cell apoptosis and growth in the hearts with atherosclerotic coronary disease and ischemic heart failure. Ann N Y Acad Sci. 2003; 1010: 687-697.

[35] Duan HF, Wu CT, Wu DL, Lu Y, Liu HJ, et al. Treatment of myocardial ischemia with bone marrow-derived mesenchymal stem cells overexpressing hepatocyte growth factor. Mol Ther. 2003; 8: 467-474.

[36] Song H, Kwon K, Lim S, Kang SM, Ko YG, et al. Transfection of mesenchymal stem cells with the FGF-2 gene improves their survival under hypoxic conditions. Mol Cells. 2005;19: 402-407.

[37] Jo J, Nagaya N, Miyahara Y, Kataoka M, Harada-Shiba M, et al. Transplantation of genetically engineered mesenchymal stem cells improves cardiac function in rats with myocardial infarction: benefit of a novel nonviral vector, cationized dextran. Tissue Eng. 2007; 13: 313-322.

[38] Matsumoto R, Omura T, Yoshiyama M, Hayashi T, Inamoto S, et al. Vascular endothelial growth factor-expressing mesenchymal stem cell transplantation for the treatment of acute myocardial infarction. Arterioscler Thromb Vasc Biol. 2005; 25: 1168-1173.

[39] Dallabrida SM, Ismail N, Oberle JR, Himes BE, Rupnick MA. Angiopoietin-1 promotes cardiac and skeletal myocyte survival through integrins. Circ Res. 2005; 96:e8-24. 


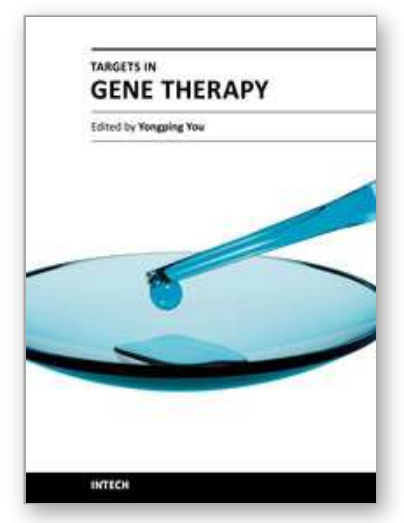

\author{
Targets in Gene Therapy \\ Edited by Prof. Yongping You
}

ISBN 978-953-307-540-2

Hard cover, 436 pages

Publisher InTech

Published online 23, August, 2011

Published in print edition August, 2011

This book aims at providing an up-to-date report to cover key aspects of existing problems in the emerging field of targets in gene therapy. With the contributions in various disciplines of gene therapy, the book brings together major approaches: Target Strategy in Gene Therapy, Gene Therapy of Cancer and Gene Therapy of Other Diseases. This source enables clinicians and researchers to select and effectively utilize new translational approaches in gene therapy and analyze the developments in target strategy in gene therapy.

\title{
How to reference
}

In order to correctly reference this scholarly work, feel free to copy and paste the following:

Jianhua Huang, Huishan Wang and Hirofumi Hamada (2011). Transplantation of Sendai Viral Angiopoietin-1Modified Mesenchymal Stem Cells for Ischemic Heart Disease, Targets in Gene Therapy, Prof. Yongping You (Ed.), ISBN: 978-953-307-540-2, InTech, Available from: http://www.intechopen.com/books/targets-in-genetherapy/transplantation-of-sendai-viral-angiopoietin-1-modified-mesenchymal-stem-cells-for-ischemic-heart-di

\section{INTECH}

open science | open minds

\author{
InTech Europe \\ University Campus STeP Ri \\ Slavka Krautzeka 83/A \\ 51000 Rijeka, Croatia \\ Phone: +385 (51) 770447 \\ Fax: +385 (51) 686166 \\ www.intechopen.com
}

\author{
InTech China \\ Unit 405, Office Block, Hotel Equatorial Shanghai \\ No.65, Yan An Road (West), Shanghai, 200040, China \\ 中国上海市延安西路65号上海国际贵都大饭店办公楼 405 单元 \\ Phone: +86-21-62489820 \\ Fax: $+86-21-62489821$
}


(C) 2011 The Author(s). Licensee IntechOpen. This chapter is distributed under the terms of the Creative Commons Attribution-NonCommercialShareAlike-3.0 License, which permits use, distribution and reproduction for non-commercial purposes, provided the original is properly cited and derivative works building on this content are distributed under the same license. 